RENATA Rocha Villela

Partidos Políticos e Regulamentação: Limites e Benefícios da Legislação Partidária no Brasil

Orientador: Prof. Dr. José LeVi Mello do Amaral JÚnior

Dissertação de Mestrado

Faculdade de Direito da Universidade de São Paulo

São Paulo

2014 


\title{
PaRtidos Políticos e RegulamentaÇão: Limites e Benefícios da Legislação Partidária no Brasil
}

\author{
Dissertação apresentada como requisito para \\ conclusão do programa de Pós-Graduação Stricto \\ Sensu, nível Mestrado, da Faculdade de Direito da \\ Universidade de São Paulo. \\ Orientador: Prof. Dr. José Levi Mello do Amaral \\ Júnior \\ Versão corrigida em 27 de maio de 2014. A \\ versão original, em formato eletrônico (PDF), \\ encontra-se disponível na CPG da Unidade.
}




\title{
Renata Rocha Villela
}

\section{Partidos Políticos e RegulamentaÇÃo: Limites e Benefícios da LEgISLAÇÃo PARTIDÁRIA No BRASIL}

\author{
Dissertação apresentada como requisito para \\ conclusão do programa de Pós-Graduação \\ Stricto Sensu, nível Mestrado, da Faculdade de \\ Direito da Universidade de São Paulo.
}

Examinado em: 12 de maio de 2014

Resultado: APROVADA

\section{BANCA EXAMINADORA}

Prof. Dr. José Levi Mello do Amaral Júnior Julgamento:

Prof. Associado José Maurício Conti Julgamento:

Prof. Dr. Pedro Rubez Jehá Julgamento:
Instituição: Universidade de São Paulo Assinatura

Instituição: Universidade de São Paulo Assinatura Instituição: Fundação Armando Álvares Penteado Assinatura 


\section{AGRADECIMENTOS}

Em primeiro lugar, a Deus, por ter me permitido chegar até aqui.

Ao meu orientador, Professor José Levi Mello do Amaral Júnior, por ter me guiado com dedicação e presteza ao longo da minha pesquisa, por ter depositado um voto de confiança em meu trabalho e por ter me ensinado a gostar ainda mais da docência e da pesquisa. Foi um prazer ser orientada por um Professor cujo amor e dedicação à docência são patentes.

Aos meus pais, Milton e Célia, a minha irmã, Daniela, e ao meu namorado, Bruno, pelo amor e apoio constantes, pela paciência e compreensão e por terem sempre acreditado em mim. Sem eles a conquista desse objetivo jamais teria sido possível.

Aos amigos Alexandre Sanson, Camila Sombra e Carolina Dalla Pacce, pelas conversas, pelas trocas de materiais, pelo incentivo, pelo carinho e pela amizade. Mesmo à distância, vocês foram essenciais para a conclusão desse trabalho.

Aos companheiros de jornada, Berardino de Vecchia Neto e Telma Rocha Lisowski, por terem compartilhado comigo os prazeres e desafios da pesquisa acadêmica e, sobretudo, pela amizade que nos uniu ao longo deste caminho.

Finalmente, aos funcionários da Seção de Pós-Graduação e da Biblioteca de Direito do Estado, em especial Fátima, Ivan e Raquel, pela ajuda inestimável. 


\section{RESUMO}

Dentre as instituições democráticas, os partidos políticos são as que gozam de menor confiança e prestígio perante a sociedade. Ainda assim, levando em consideração o papel essencial que desempenham no processo político democrático, o objetivo deste trabalho é analisar como o Direito pode contribuir para o fortalecimento dos partidos políticos brasileiros e para a reversão do atual quadro de descrença. Com esse escopo, o primeiro capítulo tratará da evolução histórica das agremiações que atuaram no cenário político nacional e da legislação partidária elaborada em cada período, a fím de identificar as origens dos problemas enfrentados atualmente e em que medida as leis já elaboradas foram suficientes para conter os desvios. Em seguida, o segundo capítulo, discorrerá sobre as principais funções exercidas pelos partidos nas arenas eleitoral e legislativa, bem como sobre a estrutura e funcionamento interno dos três maiores partidos nacionais, por meio da leitura dos seus Estatutos, com o intuito de apreender as falhas e êxitos resultantes de sua atuação. No terceiro capítulo, serão abordados o fenômeno da desconfiança e seus efeitos sobre a democracia, bem como o papel das leis na correção dos desvios, tomando como exemplo seu desempenho em outras áreas do Direito. Após, passaremos à análise dos entraves impostos à legislação partidária no Brasil, em especial a tutela excessiva da autonomia partidária. Por fim, tendo a legislação estrangeira como referência, faremos algumas sugestões com o intuito de aprimorar a atuação dos partidos políticos pátrios. Consciente de que o Direito não tem condições de resolver isoladamente as mazelas que assolam o sistema partidário brasileiro, cujas raízes estão profundamente fincadas na sociedade, esse trabalho procurará demonstrar que a Ciência Jurídica pode, ao menos, dar início às mudanças necessárias, seja incentivando os comportamentos corretos, seja proibindo e punindo os comportamentos desviados.

Palavras-chave: partidos políticos; legislação partidária; regulamentação; autonomia partidária. 


\begin{abstract}
Even though the political parties are the less prestigious and credible amongst democratic institutions, due to its unique role in the democratic political process this thesis aims to analyze how Law can contribute to the strengthening of the Brazilian political parties and to the regain of its credibility. Having this into account, the first chapter will examine the parties historical evolution on the Brazilian political scenario along with the related legislation of each period, focusing on identifying the origins of the currently problems and the role of the legislation on solving them. Afterwards, the second chapter will discuss the main functions of the political parties on the legislative and electoral arenas and the internal structure of the three main Brazilian political parties, trying to focus on the flaws and achievements of their performance. The third chapter will study the trust issues between political parties and their voters along with its effects on democracy and the role of the legislation on political parties, in comparison to its performance on the other legal areas. After this, it will be analyzed the barriers imposed to the Brazilian legislation on political parties, especially the excessive supervision of party autonomy. Finally, taking the foreign legislation as a reference, some suggestions will be made in order to improve the Brazilian political parties' performance. Considering that Law, on its own, is unable to solve the Brazilian political parties' issues, this paper aims to demonstrate that the importance of Legal Science is to initiate the necessary chances, stimulating proper behavior or punishing improper demeanor.
\end{abstract}

Keywords: political parties; legislation on political parties; regulation; party autonomy. 


\section{SUMÁRIO}

INTRODUÇÃO. .08

1. PARTIDOS POLÍTICOS BRASILEIROS: HISTÓRIA E LEGISLAÇÃO.......14

1.1. Os partidos políticos no período Imperial (1822-1889) .14

1.2. Os partidos políticos na Primeira República (1889-1930). 22

1.3. Os partidos políticos Era Vargas - Segunda e Terceira Repúblicas (1930-1937 e 1937-1945) .28

1.4. Os partidos políticos na Quarta República (1945-1964)...... .38

1.5. Os partidos políticos na Quinta República - Ditadura Militar (1965-1985). .49

2. PARTIDOS POLÍTICOS CONTEMPORÂNEOS: CARACTERÍSTICAS, FUNÇÕES E DISFUNÇÕES.

2.1. Os partidos políticos na nova ordem constitucional .62

2.2. Os partidos no eleitorado: atalho informacional e locus de discussão .67

2.3. Os partidos como organização: estrutura interna e seleção dos candidatos .77

2.4. Os partidos no governo: desempenho e efetividade na arena legislativa. .90

3. O PAPEL DO DIREITO NO FORTALECIMENTO DOS PARTIDOS POLÍTICOS. 101

3.1. Democracia, desconfiança e accountability. .101

3.2. O Direito como ferramenta promocional: o exemplo das políticas públicas 109

3.3. Princípio da autonomia partidária: entrave ou benefício? 113

3.4. Legislação partidária no Direito europeu. 118 
3.4.1. Leis partidárias na Alemanha. 121

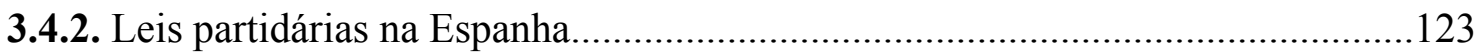

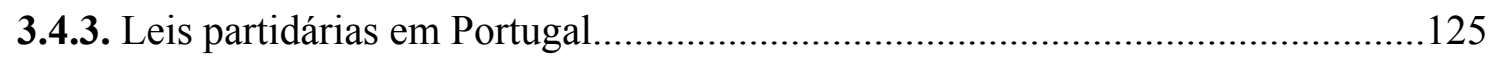

3.5. Lições da experiência comparada e sugestões para a reforma da legislação brasileira

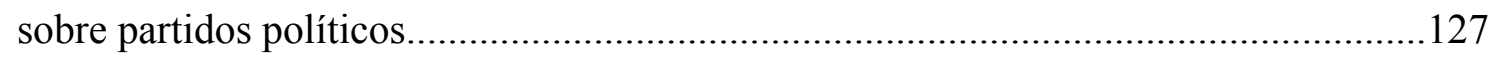

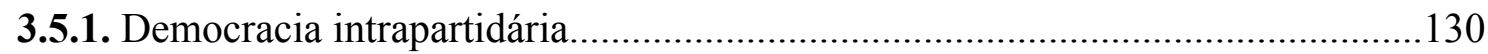

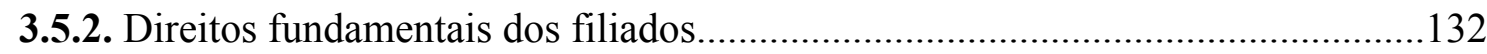

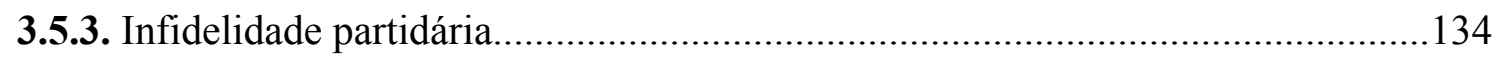

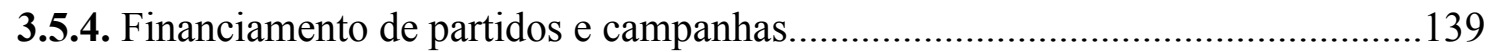

CONCLUSÃO

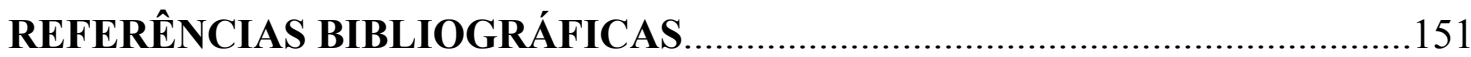

